\title{
Dispersal in an extensive continuous forest habitat: Marsh Tit Poecile palustris in the Białowieża National Park
}

\author{
Tomasz Wesołowski
}

Received: 28 May 2014/Revised: 29 June 2014/ Accepted: 18 July 2014/Published online: 11 September 2014

(C) The Author(s) 2014. This article is published with open access at Springerlink.com

\begin{abstract}
Dispersal is one of the least understood features in the life-history of organisms. Theoretical work concentrates on explaining dispersal of organisms in patchy and heterogeneous landscapes, but there are few predictions of dispersal patterns in stable, spatially extensive and largely homogenous landscapes, such as large forests. It is expected that we should observe short-distance dispersal in such places, that, to avoid competition with parents and siblings and incestuous mating, offspring should leave natal patches (natal dispersal), disperse independently in different directions, and move over distances that efficiently minimise the probability of meeting a sibling. Breeding dispersal should be very limited, site tenacity should prevail. To explore these ideas, I use observations of Marsh Tits Poecile palustris (a small passerine specialist of mature forests) made in the strictly protected part of the Białowieża National Park (Poland) over 21 years. The birds largely followed expectations: all fledglings left their natal territories and dispersed in different directions, and males moved shorter distances than females (median $=570$ vs. $1,720 \mathrm{~m}$ ). Apart from this difference, no influence of population density, fledgling time or family size was observed. No parent-offspring pairing occurred, with just one case of sibling-sibling pairing. After first breeding, individuals remained site-tenacious, as breeding dispersal distances were very short (median ca. $100 \mathrm{~m}$ ). Such behaviour renders Marsh Tit poorly adapted to cross barriers and undertake long-distance movements, and this
\end{abstract}

Communicated by F. Bairlein.

T. Wesołowski ( $\square)$

Laboratory of Forest Biology, Wrocław University,

Sienkiewicza 21, 50335 Wrocław, Poland

e-mail: tomwes@biol.uni.wroc.pl is actually observed in fragmented landscapes. Understanding dispersal patterns of organisms from extensive environments would be thus of value for basic and conservation science alike.

Keywords Poecile palustris - Natal dispersal - Breeding dispersal $\cdot$ Primeval forest $\cdot$ Incest avoidance

\section{Zusammenfassung}

Ausbreitung in einem ausgedehnten, durchgängigen Waldhabitat: Die Sumpfmeise Poecile palustris im Białowieża Nationalpark

Ausbreitung ist eines der am wenigsten verstandenen Merkmale in der Lebensgeschichte von Organismen. Theoretische Arbeiten konzentrieren sich darauf, die Ausbreitung in lückenhaften und heterogenen Landschaften zu erklären, doch gibt es nur wenige Vorhersagen bezüglich der Ausbreitungsmuster in stabilen, räumlich umfassenden und weitgehend homogenen Landschaften, wie beispielsweise großen Wäldern. Es ist zu erwarten, dass wir an solchen Standorten Ausbreitung über kurze Distanzen beobachten, dass Nachkommen ihre Geburtsorte verlassen ("natal dispersal"), um Konkurrenz mit Eltern und Geschwistern sowie Inzucht zu vermeiden, und dass sie sich unabhängig voneinander in verschiedene Richtungen ausbreiten, und zwar über Distanzen, welche die Wahrscheinlichkeit eines Zusammentreffens mit Geschwistern auf effiziente Weise minimieren. Die Brutortsstreuung („breeding dispersal”) sollte eingeschränkt sein, und Brutortstreue sollte vorherrschen. Ich habe diese Ideen anhand von Beobachtungen an Sumpfmeisen (kleinen Sperlingsvögeln, die als Spezialisten in alten Waldbeständen auftreten) im streng geschützten Teil des Białowieża 
Nationalparks in Polen über einen Zeitraum von 21 Jahren untersucht. Das Verhalten der Vögel entsprach größtenteils den Erwartungen; alle Flügglinge verließen ihren Geburtsort und breiteten sich in unterschiedliche Richtungen aus, wobei Männchen kürzere Entfernungen zurücklegten als Weibchen $($ Median $=570$ vs. $1,720 \mathrm{~m})$. Abgesehen von diesem Unterschied ließ sich kein Einfluss von Populationsdichte, Zeitpunkt des Ausfliegens oder Brutgröße beobachten. Es fanden keine Paarungen zwischen Eltern und Nachkommen statt und nur eine einzige Paarung zwischen Geschwistern. Nach ihrer ersten Brut blieben Individuen ihrem Brutort treu, da die Brutortsstreuung nur über sehr kurze Distanzen erfolgte (Median ca. $100 \mathrm{~m}$ ). Solches Verhalten bedeutet, dass Sumpfmeisen schlecht daran angepasst sind, Barrieren zu überwinden und Bewegungen über lange Distanzen zu unternehmen, und dies wird in fragmentierten Landschaften tatsächlich beobachtet. Ein Verständnis der Ausbreitungsmuster von Organismen aus ausgedehnten Habitaten wäre daher nützlich für sowohl die Grundlagen- als auch die Naturschutzforschung.

\section{Introduction}

Dispersal is one of the most important, yet least understood, features of ecology, population biology and evolution (Wiens 2001). Despite numerous efforts (e.g. three edited volumes during the last decade: Clobert et al. 2001, 2012; Bullock et al. 2002), we are still a long way from comprehending the phenomenon, with Clobert et al. (2012) concluding that "despite this interest and although the importance of this particular life-history trait is widely recognized, it is perhaps understudied with its overall importance in spatial ecology". This is mostly a consequence of the enormous difficulties of gathering observations on the movements of individuals through the landscape. Theoretical predictions cannot be tested because the data required to verify them are impossible to collect.

Hopefully, with the development of new tracking technologies (e.g. Koenig et al. 1996; Meyburg and Meyburg 2009; Stutchbury et al. 2009; Bächler et al. 2010), the impediment to data collection will be gradually removed. However, there seem to be additional, and conceptual, reasons hindering progress. Theoreticians tend to treat dispersal as a unique phenomenon that could be explained with a single set of rules, in the hope of a general theory of dispersal. However, achievement of this goal could prove impossible, as qualitatively different phenomena which have only one feature in common (organisms permanently changing their location at some point during their life) are combined under the same name. In a recent review, Matthysen (2012) underlined this multitude of causes and processes of dispersal in different groups of organisms. It seems that, even for a single group of organisms (birds) using one habitat type (forest), it would be impossible to formulate a singular explanation. Desrochers et al. (1999) concluded their review by saying "the taxonomic variety of response to forest fragmentation is bewildering. It would thus appear futile to search for species-independent theory of fragmentation, even with forest specialists only".

Therefore, it seems more profitable to recognise these qualitative differences at the outset and to propose more specific explanations of dispersal in these different groups, including birds. Evolutionary history of the organisms concerned should always be considered. For instance, it is crucial to know whether living in a fragmented landscape is deeply embedded in a species' evolutionary past, and whether it originated in naturally patchy landscapes, or if this is a novel situation in which they have to cope for the first time. We should expect to detect well-developed mechanisms for, e.g., crossing hostile habitats only in the former group, while these could be largely missing in the latter, which had no previous need to evolve them. Another qualitative difference to consider is the compulsion to disperse, and whether the organism is an obligatory disperser (i.e. cannot complete its life cycle without successfully dispersing), or a facultative one (dispersal is possible but not essential, and the life cycle could be completed without moving from the birthplace). For obligatory dispersers, the reasons to disperse are twofold (reviewed in Southwood 1962): (1) organisms have to switch habitats during their life cycle, e.g. amphibians, numerous holometabolous insects or host-switching parasites, and (2) organisms live in ephemeral habitats, e.g. places which are useable for periods shorter than their life-span, or the habitats do not remain suitable for more than one generation. Failure to disperse in such species is strongly selected against (sterile death), thus all must have well-developed dispersal mechanisms. Southwood (1962) even considered the ability to colonise unstable or temporary habitats to be the prime factor selecting for evolution of dispersal. On the other hand, in organisms living in permanent (i.e. lasting for many generations) habitats, selection for the development of dispersal mechanisms would not be so strong. Apart from habitat permanence, its spatial extent is also critically important. Some organisms live in naturally fragmented habitats and must frequently cross inhospitable areas, while others living in extensive (i.e. much larger than the range of the organisms' possible displacements) habitats can spend whole their lives within it.

Dispersal is considered to be costly due to increased energetic and physiological expenditures on movement, the development of locomotory structures enabling this movement, and the increased exposure to predation and starvation during the dispersal process and/or from reduced 
familiarity with ecological and social conditions in novel environments (Greenwood 1980; review in Bonte et al. 2012). Thus, if dispersal is costly, then site-tenacity (nondispersal) should be advantageous wherever possible, or it should be outweighed by the benefits of dispersal. While site-tenacity is a non-option in all obligatory dispersers, it could be favoured in organisms inhabiting long-lasting and spatially extensive habitats. Frequent evolution of flightlessness in insects in forests, which tend to be both persistent and spatially extensive habitats (Southwood 1962; Roff 1994; Hunter 1995), lends some support to this idea.

There is an enormous body of theoretical and modelling work devoted to predicting and explaining dispersal of organisms living in patchy, heterogeneous landscapes (summarised in Clobert et al. 2001, 2012; Bullock et al. 2002), yet there are few predictions of dispersal patterns in organisms living in stable, spatially extensive and largely homogenous landscapes, such as large forests. Should such organisms disperse at all? Hamilton and May (1977) answered affirmatively, suggesting that "substantial dispersal is to be expected when the habitat is uniform, constant, and occupied completely". They argued that offspring should leave natal patches to avoid competition with their parents and siblings, and, as natal patches are already occupied, the only way to find a vacant home-range is to look elsewhere. Remaining in the same place and waiting for parental death is an alternative solution, but settling away from their kin also avoids inbreeding, as offspring would be less likely to mate with close relatives (Greenwood 1980). Hamilton and May (1977) do not provide any predictions of how far, or in what direction, an organism should disperse, nor of any effects of social status on dispersal. One can propose, though, that, in organisms with overlapping generations and simultaneously producing multiple offspring, all young should disperse to avoid competition with surviving parents, but settling just outside their parents' ranges should suffice. However, this would not prevent competition among siblings, and, to minimise this, young should (1) disperse independently in different directions, and (2) settle at a distance that efficiently minimises the probability of meeting a sibling. As the probability of such an occurrence declines very quickly with distance, moving only a couple of home ranges distant from the natal patch would suffice. As such, short-distance dispersal should prevail and be achieved without leaving the natal habitat type. Therefore, in this group of organisms, we should not expect to find morphological, physiological or behavioural adaptations for long-term dispersal across inhospitable environments. Loss of flight in forest insects (see above) and "psychological flightlessness" (Diamond 1981) of numerous tropical forest birds, which are extremely reluctant to cross even narrow open spaces (Desrochers et al. 1999; review in Moore et al. 2008), indicate that, in permanent, extensive habitats, such adaptations are selected against.

Every dispersing organism has to perform its dispersal movement once, shifting between its place of birth and site of reproduction, termed natal dispersal (Greenwood 1980). Additionally, the iteroparous organisms have to decide what to do between consecutive breeding attempts, whether to stay in the same place or to move again, representing breeding dispersal (Greenwood 1980). It is generally assumed that an organism living in a persistent habitat where it successfully reproduced should be philopatric, staying in the same place for subsequent breeding attempts (reviews in Newton 1979; Greenwood 1980; Greenwood and Harvey 1982; Wesołowski 2006). Such individuals should be more prone to dispersal after breeding failure, but, if conditions are homogenous over large areas, there would be no clear benefits of moving, as staying or departing would have similar fitness effects (e.g. Wesołowski 2006). As an individual leaving a patch would have to trade all advantages of fidelity (familiarity, social dominance) for all costs of finding a new place and becoming established, it would probably not be worthwhile. Thus, it is expected that, in such stable, homogenous environments, breeding dispersal would be very limited and site tenacity should prevail.

To explore these ideas, I use observations of natal and breeding dispersal of Marsh Tits Poecile palustris (a small passerine weighing 10-11 g). Previous studies carried out in fragmented woods (Berndt and Winkel 1987; Nilsson 1989, Amann 1997; Markovets 2001a; Broughton et al. 2010) suggest that this species is a specialist of mature forests, and seems to have short dispersal distances. Here, I use observations on a population living in the middle of large (ca. $1,500 \mathrm{~km}^{2}$ ) expanse of the Białowieża Forest (Polish/Belarussian border), where the last remnants of the primeval forests of temperate Europe are protected (Tomiałojć et al.1984; Faliński 1986; Wesołowski 2007). Observations were carried out in the strictly protected part of the Białowieża National Park (hereafter BNP). Free of direct human interference, the resident, sedentary Marsh Tits breed in non-excavated holes (Wesołowski 1989, 1996, 1999, 2001), which are superabundant (Wesołowski 2001). The majority of holes persist until the following season (Wesołowski 1995, 2001) and they are often reused (Wesołowski 2006). Marsh Tits in BNP (and elsewhere) form permanent pairs breeding in exclusive territories of ca. 5 ha (Amann 1997; Broughton et al. 2006; own unpublished data), and rear one brood per year (Wesołowski 1998, 2000, 2002).

Furthermore, I compare the BNP results with observations of Marsh Tit dispersal in fragmented landscapes (for references, see above) to examine the effect of fragmentation on dispersal in this species. I conclude with some 


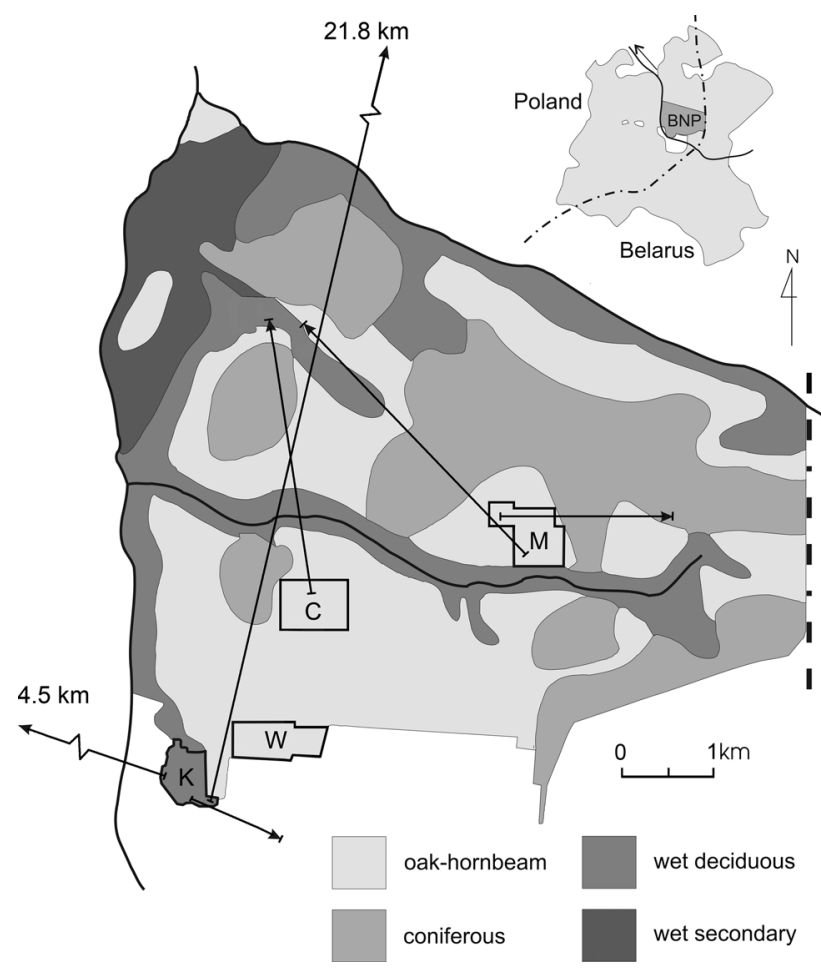

Fig. 1 Distribution of major habitat types and permanent study plots $(K, C, W$ and $M)$ in the strictly protected part of the Białowieża National Park (BNP), and the location of BNP within the Białowieża Forest (after Wesołowski et al. 2002, modified). Natal dispersal directions and distances of Marsh Tits Poecile palustris hatched in the study plots but recorded outside are also shown

remarks on the evolution of dispersal in long-lasting (permanent), spatially extensive habitats.

\section{Methods}

\section{Study area}

The Białowieża Forest complex is situated in the middle of the European plain, at the Polish/Belarusian border (coordinates of Białowieża village: $52^{\circ} 41^{\prime} \mathrm{N}, 23^{\circ} 52^{\prime} \mathrm{E}$ ). The western part of the forest $\left(613 \mathrm{~km}^{2}\right.$, ca. $45 \%$ of the area) lies in Poland, and represents a remnant of the vast lowland forests that once covered large parts of temperate Europe. Its present unique features result from its considerable size and an exceptionally good state of preservation (Tomiałojć and Wesołowski 1990; Wesołowski 2005, 2007). The majority of the tree stands in the Polish part are now under management, but a $47.5-\mathrm{km}^{2}$ block of the best preserved primeval old-growth stands, situated in the centre of the forest (Fig. 1), has been retained within the strictly protected part of BNP.

The preserved primeval stands are multi-storey, mixedspecies, and uneven-aged. They contain many veteran trees (the tallest Norway spruce Picea abies can reach $50 \mathrm{~m}$, and several other species reach $42-45 \mathrm{~m}$ ). The girth at breast height of the thickest trees ranges from ca. $410 \mathrm{~cm}$ (Norway maples Acer platanoides and aspens Populus tremula) to ca. $740 \mathrm{~cm}$ (pedunculate oak Quercus robur; Niechoda and Korbel 2011). They also contain large amounts of standing dead timber and fallen trees $(20-25 \%$ of total wood volume; Bobiec 2002). For more information and photos, see Tomiałojć and Wesołowski (1990, 2004), Wesołowski (2007) and Wesołowski et al. (2010).

Data on Marsh Tit dispersal were gathered in four sample plots of 33-54 ha within the BNP, spaced 1-2 km apart, and covering a total area of ca. 185 ha (Fig. 1). Plots $\mathrm{C}$ and $\mathrm{M}$ were situated in the forest interior, whereas Plots $\mathrm{W}$ and $\mathrm{K}$ bordered open, formerly cultivated, areas to the south and/or west (Fig. 1). These edges were not sharp, however, as the plots were surrounded by a dense belt of young trees. Three plots $(\mathrm{C}, \mathrm{M}$, and $\mathrm{W})$ were situated in oak-lime-hornbeam stands composed mostly of hornbeam Carpinus betulus, lime Tilia cordata, pedunculate oak, spruce, and continental maple. The fourth plot (K) was located in a swampy riverine forest made up mainly by alder Alnus glutinosa, ash Fraxinus excelsior, and spruce. It also contained some drier hornbeam-covered 'islands' along the edges (for detailed descriptions, see Wesołowski et al. 2002, 2006,; Tomiałojć and Wesołowski 1990, 2005). No artificial food nor nest boxes were available, and birds bred exclusively in natural tree holes (Wesołowski 1996, 2001).

\section{Field observations}

Observations were carried out in 1993-2013. Every spring intensive searches for nests, aimed at finding all breeding holes, were made in the four plots (Wesołowski 2002). To establish the number and distribution of Marsh Tit breeding pairs in the plots, birds were followed and their movements noted on field maps just before the onset of breeding. Many of the birds were colour-ringed (see below), which facilitated mapping work and nest searches. All marked birds were carefully searched for in the plots (they usually stayed in the same territory as in the previous year or moved to a neighbouring territory; Wesołowski 2006). During these searches, we also recorded the presence of any birds wearing only standard metal rings, which were fitted to nestlings in previous years (see below). Additionally, ringed Marsh Tits were casually searched for in all study plots used for bird censusing (Wesołowski et al. 2010) and in other parts of the Białowieża Forest.

To gather data on the fate of nests, the breeding holes were checked regularly, mostly from the ground. The observation distance varied with the situation of hole and the parents' behaviour, in most cases being within ca. 
$15-50 \mathrm{~m}$. The frequency of nest visits depended on the stage of the nesting cycle (see below). After incubation had been recorded, the nest was inspected to count eggs and to predict the presumable hatching date. Lower holes were inspected from a ladder, the higher ones by climbing. A flashlight bulb fixed to a flexible wire was used to light the cavity interiors. In some holes, additional usage of a small mirror on a bendable handle was necessary. It was usually possible to find holes of all pairs breeding within the plots, as well as the majority of those nesting in their close vicinity. The majority of them were accessible, and over $90 \%$ of holes could be directly inspected. After hatching was recorded, holes with young were visited again and the age of nestlings was established following the criteria of Winkel (1970). This allowed for predicting dates of ringing of nestlings and adults, as well as fledging dates. Unringed adults or birds wearing only metal rings were caught in door-traps or mist-nets placed at the hole entrance, and colour-ringed. This was done only in calm weather, at holes with 10- to 14-day-old young. The majority of territorial birds (up to $90 \%$ in some years) were ringed by the end of the season. Young were extracted from holes, using a "lasso" made of a thick guitar string attached to a strong wire, and ringed when 13-14 days old.

Around the expected time of fledging, the holes were observed from a distance every ca. $24 \mathrm{~h}$, up to the day on which no parents were observed bringing food. If, on the previous day, young were at least 18 days old (the youngest age of fledging of undisturbed broods; Wesołowski 2000) and no signs of attempted robbing by predators were detectable, the nest was considered to be successful. If no feeding was observed at a hole containing young about to fledge (16-17 days old), we searched for parent birds to check whether they were collecting food for prematurely fledged young. If they were, the nest was classified as successful. All other cases of premature cessation of parental activity (no signs of parent presence during an hour observation session) were treated as nest failure. As such, derived fledging dates were precise to \pm 1 day.

\section{Data analysis}

Each year, the location of breeding holes was marked on detailed maps of the plots in reference to permanent marks forming a $50 \times 50 \mathrm{~m}$ grid. The location of holes was made with $\pm 5 \mathrm{~m}$ precision. Distances between the location of holes of the same bird in consecutive years were measured on the maps (rounded to $10 \mathrm{~m}$ ). The maximum dispersal distance detectable within a single plot ranged from 950 (plot $\mathrm{K}$ ) to $1,250 \mathrm{~m}$ (plot $\mathrm{M}$ ), the maximum detectable dispersal distance between the neighbouring plots was from $1.9 \mathrm{~km}$ (plots K-W, Fig. 1) to $3.1 \mathrm{~km}$ (plots $\mathrm{C}-\mathrm{M}$ ). The largest dispersal distance detectable within the study areas (plots K-M, Fig. 1) amounted to $5.5 \mathrm{~km}$ and dispersal falling within $95 \%$ of the linear inter- and intra-plot distances within this limit could be measured. Only birds dispersing between 3.6 and $3.9 \mathrm{~km}$ would fall outside of all plots, although such distances could still be detected from the casual searches.

Natal dispersal amounted to the distance between the position of the birth hole of a bird and the breeding hole in the following year. Breeding dispersal was expressed as the distance between the breeding holes of the same bird in successive years.

To account for inter-year differences in the timing of breeding, we calculated relative fledging dates, i.e. differences between an absolute fledging date and the median fledging dates in the respective seasons. The calculated fledging dates were then used to check whether the timing of fledging within a season influenced the natal dispersal distance.

Family size refers to the number of nestlings at ringing (13-14 days old), as long as no traces of nestling mortality (attempted nest robbing, dead young in nest after fledging) past that age were detectable. This was true in almost all (72/74) broods from which the analysed birds originated.

Population density was expressed as a summed density (individuals/10 ha) of adult and juvenile Marsh Tits at the end of the breeding season, across the whole study area. As all territorial birds were paired, adult density equalled the density of territories at the onset of spring multiplied by two. The juvenile density was calculated as territory density $\times$ proportion of successful broods $\times$ family size. As complete nest histories were largely available, there was no need to apply Mayfield corrections, as the proportion of successful broods was calculated directly from the field data. Because year-to-year changes in numbers and breeding performance of Marsh Tit in individual plots were highly synchronous (Wesołowski 1998; Wesołowski et al. 2006, 2010), a single density index was calculated for each year. The values calculated this way are somewhat exaggerated as adult mortality during the breeding season (rather low, Wesołowski and Rowiński 2006; own unpublished data), nor the juvenile mortality between fledgling and gaining independence were not accounted for. There are no data from BNP on the latter aspect, but results from Sweden (Nilsson and Smith 1985) suggest that it could also be low.

\section{Statistics}

Nonparametric tests were generally used, except a GLM analysis of effects of fledging date, family size and population density on the natal dispersal distance. All statistical analyses followed formulae in Statistica 10.0 (StatSoft 2011). All probability values shown are two-tailed. 
Table 1 Pattern of natal dispersal of Marsh Tits Poecile palustris in BNP

\begin{tabular}{llrrrrrr}
\hline Natal plot & \multicolumn{3}{l}{ Breeding plot } & & & \multicolumn{2}{c}{ Number of pairs } \\
\cline { 2 - 3 } \cline { 8 - 8 } & $\mathrm{K}$ & $\mathrm{W}$ & $\mathrm{C}$ & $\mathrm{M}$ & & Mean & SD \\
\hline $\mathrm{K}$ & $\mathbf{3}$ & 6 & 1 & 2 & & 5.6 & 1.05 \\
$\mathrm{~W}$ & 5 & $\mathbf{1 3}$ & 3 & 2 & 9.9 & 1.39 \\
$\mathrm{C}$ & 0 & 6 & $\mathbf{1 1}$ & 4 & 7.7 & 1.95 \\
$\mathrm{M}$ & 1 & 1 & 3 & $\mathbf{1 0}$ & 9.9 & 2.30 \\
\hline
\end{tabular}

Number of birds born in different plots found breeding in individual areas. The number of pairs breeding in individual plots (source size) are also shown. Plots arranged along increasing distance along SW-SE axis (see Fig. 1). Bold values indicate the number of birds breeding in their natal plots

Table 2 Natal dispersal of individual Marsh Tit siblings from the same nest

\begin{tabular}{lllcl}
\hline $\begin{array}{l}\text { Natal } \\
\text { plot }\end{array}$ & Sex & $\begin{array}{l}\text { Distance } \\
(\mathrm{m})\end{array}$ & $\begin{array}{l}\text { Direction } \\
\left({ }^{\circ} \text { from } \mathrm{N}\right)\end{array}$ & $\begin{array}{l}\text { Breeding } \\
\text { plot }\end{array}$ \\
\hline $\mathrm{C}$ & Female & 2,770 & 74 & $\mathrm{M}$ \\
& Male & 1,460 & 185 & $\mathrm{~W}$ \\
$\mathrm{C}$ & Female & 2,220 & 65 & $\mathrm{M}$ \\
& Male & 650 & 275 & $\mathrm{C}$ \\
$\mathrm{K}$ & Female & 2,580 & 35 & $\mathrm{C}$ \\
& Male & 1,320 & 70 & $\mathrm{~W}$ \\
$\mathrm{M}$ & Female $^{\mathrm{a}}$ & 920 & 125 & $\mathrm{M}$ \\
& Male $^{\mathrm{a}}$ & 920 & 125 & $\mathrm{M}$ \\
\hline
\end{tabular}

${ }^{\text {a }}$ Incestuous pair

\section{Results}

\section{Natal dispersal}

Distances between the place of birth and breeding locality were recorded in 29 Marsh Tit females and 45 males born in 1993-2012. For $73 \%$ of birds, these were their first breeding places; the other birds were identified only when breeding for their second or subsequent time. The inclusion of the latter group was justified, because the breeding dispersal distances, in comparison with the natal dispersal movements, were very short (see below). This introduced some "noise" in the data, yet it allowed for maximisation of the sample size.

The birds dispersed from the their birth places in different directions; the longest recorded movement was of a bird hatched in plot $\mathrm{K}$ and caught in the autumn of the same year at the northern edge of the Białowieża Forest, $21.8 \mathrm{~km}$ NNE from its birth place (Fig. 1; not included in further analyses). Most often, birds were found breeding within their natal plots (Table 1), but those hatched in one plot could be found breeding in any other (Table 1). Exchange of young occurred more often between neighbouring plots than between more distant ones (cf. Table 1;

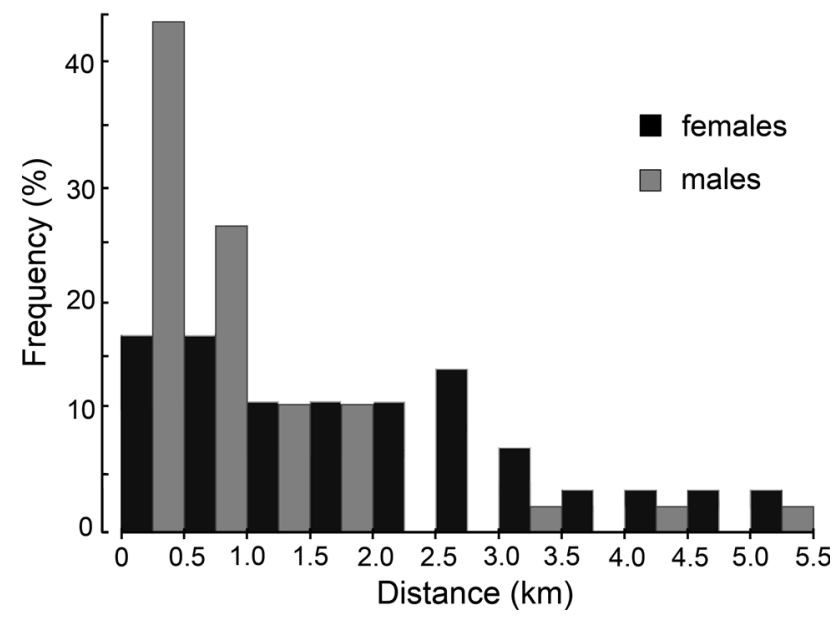

Fig. 2 Frequency distribution of Marsh Tit natal dispersal distances in BNP in females $(n=29)$ and males $(n=45)$

Table 3 Relationship between relative fledging date, relative brood size, and population density and natal dispersal distances of female and male Marsh Tits in BNP

\begin{tabular}{llllll}
\hline Predictor variable & \multicolumn{2}{l}{ Females } & & \multicolumn{2}{l}{ Males } \\
\cline { 2 - 3 } & $F$ & & & $F$ & $P$ \\
\hline Fledging date & 0.07 & 0.79 & & 0.21 & 0.65 \\
Family size & 3.10 & 0.09 & & 0.03 & 0.86 \\
Population density & 0.05 & 0.83 & & 0.42 & 0.52 \\
\hline
\end{tabular}

Results of a GLM analysis

Fig. 1). Fledglings from the same brood which were subsequently located after settling had dispersed in opposite directions (Table 2), though one case of sister and brother dispersing in the same direction and forming an incestuous pair was also recorded (their clutch and brood size were standard for that season, but the brood was partially reduced because of nest soaking after rain). No bird remained in its natal territory, and in all cases in which parents and offspring were known to survive $(n=16$ females, 24 males), the no inter-generational pairings were observed.

The natal dispersal distances of males (median $=570 \mathrm{~m}, \quad Q_{25-75} \%=390-1,720 \mathrm{~m}$, Fig. 2) were three times shorter than those of the females (median $=1,720 \mathrm{~m}, Q_{25-75} \%=600-2,770 \mathrm{~m}$ ). These differences were significant: Mann-Whitney test, $Z=3.52$, $P<0.0005$. Apart from this intersexual difference, the dispersal distances were not related to any of the measured factors (Table 3); early- and late-fledged young, and young from the smaller and larger broods travelled similar distances (Fig. 3). Variation in population density did not produce any visible effect on the dispersal distances of individual birds (Fig. 3). Also, population density was not related to the annual mean dispersal distance in females 

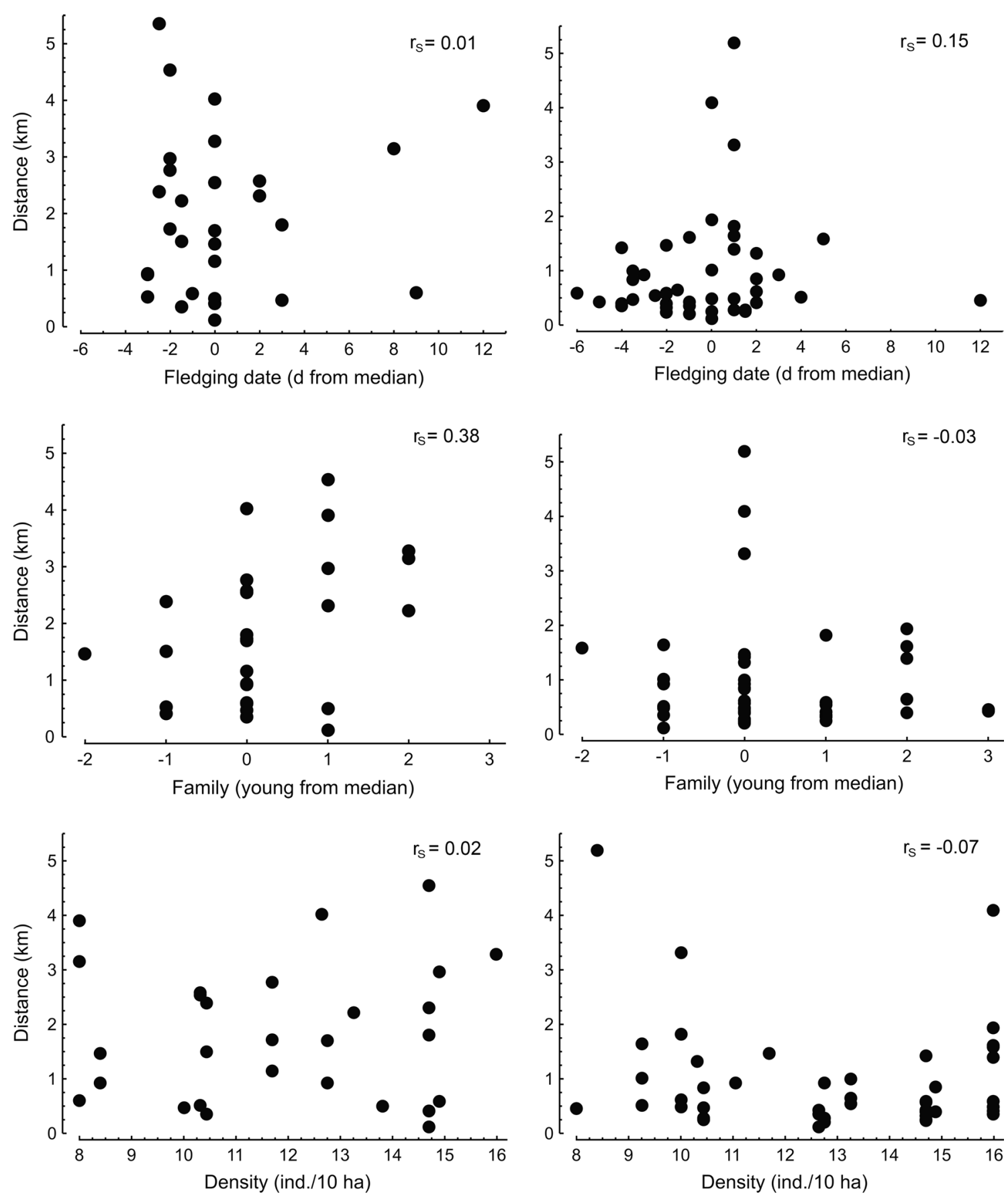

Females

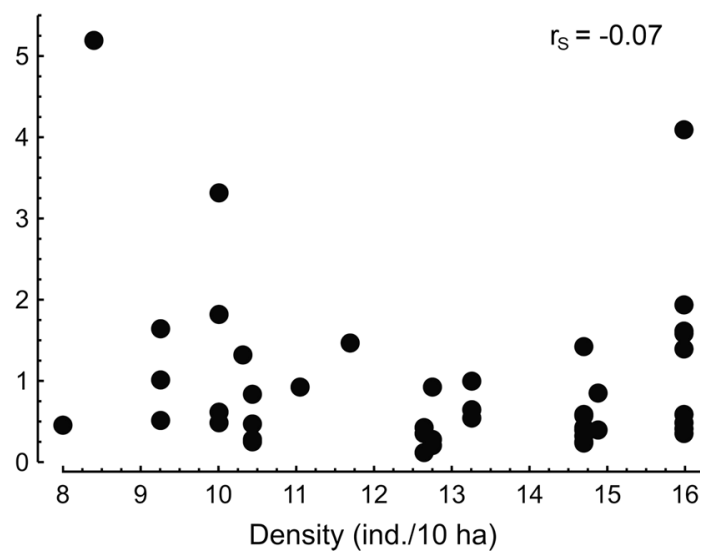

Males

Fig. 3 Distribution of female and male Marsh Tit natal dispersal distances in BNP in relation to relative fledging dates (upper), relative family size (middle) and population density (lower). Details of how the values of independent variables were calculated are given in "Methods"

$\left(n=13, \quad r_{\mathrm{s}}=0.17, P=0.57\right)$ nor in males $(n=14$, $\left.r_{\mathrm{s}}=-0.17, P=0.54\right)$.

Breeding dispersal

From the first breeding onwards, adult birds remained in the same area and no dispersal between study plots was observed. In consecutive years, the birds either used the nest hole from the previous year (distance $=0 \mathrm{~m}$ ) or moved to a new hole over a distance of up $520 \mathrm{~m}$ (one male, Fig. 4). Generally, the distances moved between years were much shorter than this, with a median of $100 \mathrm{~m}$ $\left(Q_{25-75} \%=30-140 \mathrm{~m}, n=12\right)$ in females and $70 \mathrm{~m}$ $\left(Q_{25-75} \%=40-140 \mathrm{~m}, n=25\right)$ in males. The distances 


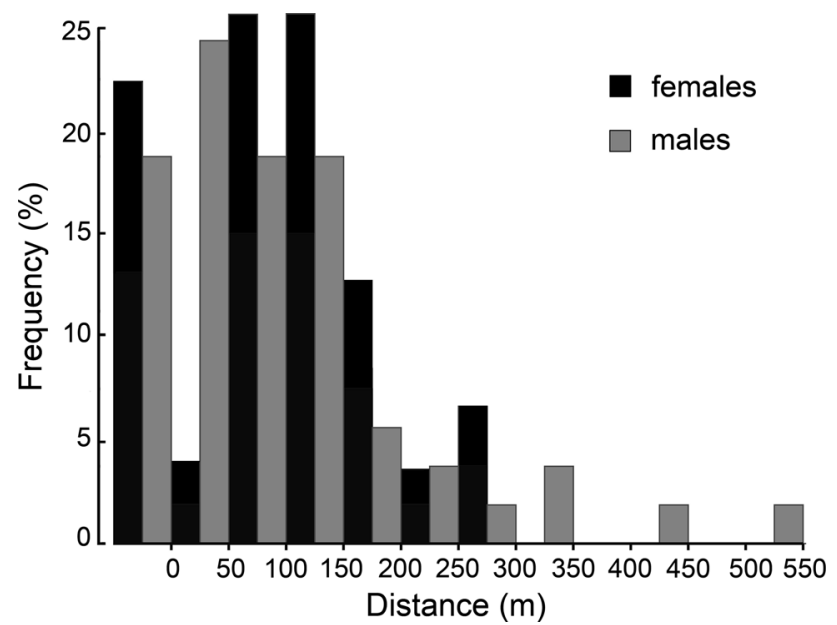

Fig. 4 Frequency distribution of Marsh Tit breeding dispersal distances in BNP in females ( $n=31$ movements of 12 individuals) and in males ( $n=53$ movements of 25 individuals)

moved did not differ substantially between the sexes (Mann-Whitney test, $Z_{\text {adjusted }}=0.77, P=0.44$ ). Additionally, long-lived individuals (breeding for 5-9 years, $n=6$ ) remained in very restricted areas, with the maximum distance between nest holes ranging over only 150-240 $\mathrm{m}$. The breeding dispersal distances were an order of magnitude shorter than those of natal dispersal (cf. Figs. 2, 4). This difference was highly significant, both in females (Wilcoxon Matched Pairs test, $Z=3.06$, $P=0.0022)$ and in males $(Z=4.37, P<0.0001)$.

\section{Discussion}

Natal dispersal

This study was conducted within a set of permanent plots within an extensive habitat matrix. As such, birds settling within the plots had a $100 \%$ probability of being detected, while birds settling outside of the plots had only a very small chance of being found. Moreover, the maximum dispersal distance which could be recorded within the study areas amounted to $5.5 \mathrm{~km}$, and birds moving any further had only a remote chance of being detected. Therefore, the distribution of natal dispersal distances and dispersal directions found in this study is not an unbiased sample. Constraints on the distribution of dispersal distances constitutes a common problem for studies within limited areas, as they are usually too restricted to detect long-distance dispersal (Barrowclough 1978; Baker et al. 1995; Koenig et al. 1996).

However, the ringing recoveries from other Marsh Tit populations (which are unaffected by this problem) show that $64 \%$ of birds were found up to $6 \mathrm{~km}$ from the birth places, $87 \%$ up to $13 \mathrm{~km}$, and all within $100 \mathrm{~km}$ (Rost 1988). In Britain, $85 \%$ of 108 recoveries were within $5 \mathrm{~km}$ (Sellers 1984), with only three above $20 \mathrm{~km}$ (review in Cramp and Perrins 1993). There is just one reliable observation of a Marsh Tit moving more than $100 \mathrm{~km}$ : a bird was observed in Scotland, at least $135 \mathrm{~km}$ from the nearest known breeding population (Hamlin 2008).

Therefore, local studies of dispersal (summarised in Table 4), in which movements of up to 5-7 km could be detected, probably encompassed the majority of dispersal events in local populations. As the detection range of these studies was similar to that in BNP, the results could be cautiously compared across the sites. However, within-area comparisons in the current study are not compromised, as all classes of Marsh Tit in BNP were equally affected by the constraints of the study design. The natal dispersal distances recorded in BNP were within the range of those recorded elsewhere, except for the Russian study, where Marsh Tits dispersed over much greater distances (Table 4). The latter were probably due to specific structural features of the local landscape, as birds there bred in isolated deciduous patches embedded in a very narrow belt of coniferous forest stretching along the Curonian Spit (Bardin et al. 1992; Markovets 2001a, b). Females in BNP dispersed greater distances than males, as observed in the majority of other areas studied (Table 4), although this difference was most pronounced in BNP. As such, females were much less likely than the males to settle within the study plots. This probably accounted for the lower proportion of females (39\%) among the detected recruits, despite their equal proportion at fledging (Czyż et al. 2012). Such female-biased dispersal seems characteristic for many birds (reviews in Greenwood 1980; Clarke et al. 1997; Paradis et al. 1998). For male Marsh Tits, which have to establish a territory, they were probably more pressed to do so than females as soon as possible after departure from the natal territory. The females, being less constrained, could possibly spend more time roaming over larger areas to select both a site and a mate (Nilsson 1989; Amann 1997).

All young Marsh Tits left their natal territories in BNP and in other areas (Berndt and Winkel 1987; Nilsson 1989; Bardin et al. 1992; Amann 1997; Broughton et al. 2010). Additionally, observations from other areas show that young Marsh Tits depart their natal areas immediately after becoming independent, and leave without any aggression from parents or siblings (Nilsson and Smith 1985; Amann 1997). Thus, It appears that emigration from the birth place constitutes a compulsory phase in the Marsh Tit life cycle, and that the decision to leave per se is independent of local environmental and social factors. The latter, though, could still have some impact on the distances travelled. The idea that dispersal distances should change with varying 
Table 4 Sexual differences in natal dispersal distances of Marsh Tits in different study areas

\begin{tabular}{|c|c|c|c|c|c|c|}
\hline \multirow[t]{2}{*}{ Area } & \multicolumn{2}{|l|}{ Female } & \multicolumn{2}{|l|}{ Male } & \multirow{2}{*}{$\begin{array}{l}\text { Ratio } \\
\text { (female/male) }\end{array}$} & \multirow[t]{2}{*}{ Source } \\
\hline & Meters & Territ. & Meters & Territ. & & \\
\hline England & 1,065 & 3.1 & 705 & 2.6 & 1.5 & Broughton et al. (2010) \\
\hline Sweden & 1,400 & 5.5 & 1,000 & 3.6 & 1.4 & Nilsson (1989), personal communication \\
\hline Switzerland & 1,125 & - & 635 & - & 1.7 & Amann (1997) \\
\hline Germany & 500 & - & 500 & - & 1.0 & Berndt and Winkel (1987) \\
\hline NW Russia & 4,470 & - & 3,510 & - & 1.3 & Markovets (2001a) \\
\hline BNP & 1,720 & 6.4 & 570 & 2.1 & 3.0 & This study \\
\hline
\end{tabular}

Mean or median values (depending on values provided) of dispersal distances expressed as physical distance, as well as the number of territories transversed, if available

densities of conspecifics is popular among theoreticians, yet empirical support for this notion is rather scant. In a recent critical review, Matthysen (2005) found that, despite the frequently expressed view of the role of increasing density in stimulating dispersal, signs of such a relationship were detected only in 7 of 21 avian studies testing this idea. Among the results he questioned was a study by Nilsson (1989), showing that dispersal distances in Swedish Marsh Tits increased when population density increased. Matthysen (2005) argued that this could be a spurious result because the number of years studied was very small (only four), and one particular year appeared to greatly influence the outcome. Results from the current study in BNP, based on 14 years of observations during which the post-fledging density of Marsh Tits varied over a much larger range than in Sweden, did not show any relationship between density and dispersal distance. Furthermore, changes in density within a season (the first young of the season face 2-3 times lower population density than the last ones hatched), or variation in family size, did not influence the dispersal distances in BNP, in contrast to the Swedish study (Nilsson 1989). Extending dispersal distances in response to increased local crowding could only help where there was some density gradient, and that by moving further away the birds would be able to find less crowded areas. This was not the case, though, in the largely homogenous BNP, where the whole area was saturated with birds and the population density and breeding productivity varied across all areas in parallel (see below).Therefore, all locations within a bird's reach were equally crowded, and in such conditions the extension of dispersal distances would probably not offer any benefit.

The costs of dispersal movements themselves often represent the largest costs of the emigration-transfer-settlement sequence (reviewed in Bonte et al. 2012). These appeared negligible in BNP, as Marsh Tits moved through suitable habitat and an entire dispersal distance could be covered in a single flight of a few minutes in duration, and birds probably covered greater distances while foraging within a territory during a single day. Therefore, the costs of transfer could not account for the dispersal patterns found in BNP. As the costs were negligible, some individual variation in dispersal propensity could have been tolerated, dispersing further than the necessary minimum would not be selected against. However, though relatively unimportant from the individual perspective, and relatively infrequent, the displacements over tens of kilometres could have profound population effects. The regular exchange of individuals (and genes) over long distances would prevent local differentiation, and would result in ecologically and genetically unified populations inhabiting extensive areas (review in Williamson 2002). The role of such long-distance dispersers could be even greater in Marsh Tits living in highly fragmented woods (see below).

It was impossible to check whether dispersal distance affected Marsh Tit breeding performance in BNP, as found in some other species (Pärt 1991; Pasinelli et al. 2004), because only effective dispersal (Greenwood 1980) was recorded in the current study, and adults were caught and identified only when feeding large young. The sample was therefore biased towards successful individuals, which had managed to settle, survive until the breeding season, and whose broods had not been destroyed. However, as Marsh Tits in all the study plots commenced breeding at the same time (Wesołowski 1998), laid a similar number of eggs (Wesołowski 2000), and were equally successful in production of young (Wesołowski 2002), it would not matter whether they dispersed for a short distance and settled in the natal plot or moved to some distant place. The two-way exchange of birds between neighbouring plots in BNP also indicated that birds perceived all areas as equally attractive, and, in such conditions, dispersal distance should not affect breeding performance.

\section{Breeding dispersal}

After their first breeding, Marsh Tits in BNP remained in the same area of forest for life. Although they often shifted 
location of the breeding holes between years (Wesołowski 2006), the median distance between consecutive holes was very short (70-100 $\mathrm{m}$ in both sexes), and the maximum distance between nest holes used by the same birds in 5-9 breeding years only varied between 150 and $240 \mathrm{~m}$. Breeding birds were similarly site-tenacious in other studies: in Lower Saxony, Germany, $>95 \%$ bred within $<300$ m of the previous year's nestbox (Berndt and Winkel 1987); in Switzerland, $87 \%$ of birds remained in the same or neighbouring territory in subsequent years (Amann 2003); and in England, $95 \%$ of birds remained in the same territory between years (Broughton et al. 2010). Reports from other areas indicate the same pattern (Rost 1988; Markovets 2001a, b). The rare cases in which greater territory shifts are observed are mostly due to the death of a mate, disappearance of neighbouring territory owners, or (rarely) divorces (Amann 2003; Broughton et al. 2010). It appears, thus, that such site faithfulness is a species-specific trait of the Marsh Tit. As an extreme example of this behaviour, Rost (1988) described an individual spending up to 11 years in the same forest patch, of just few hundred metres across, a distance which could be flown in a matter of seconds. Such extreme site tenacity could only evolve in very predictable, long-lasting habitats where suitability remained adequate over many years. The old-growth forest habitats used by Marsh Tits in BNP had such characteristics, and changed very slowly (Wesołowski et al. 2010), so from the perspective of a Marsh Tit's lifetime (a decade or less), the habitat structure remained largely unchanged.

\section{Ultimate causes of Marsh Tit dispersal}

By leaving their natal patches, young birds can achieve twofold benefits. Firstly, they avoid competition with their parents and siblings (Hamilton and May 1977) and, secondly, by settling away from their kin, the young would also avoid incestuous breeding (Greenwood 1980). Marsh tit siblings in BNP probably dispersed independently of one another, in disparate directions, as was surmised in Switzerland (Amann 1997). However, in Lower Saxony, Berndt and Winkel (1987) observed that siblings (four cases) dispersed in similar directions, although, as in other areas (see above), they settled at different distances. Such a pattern of dispersal would, to a large extent, prevent incestuous mating with siblings. Furthermore, because of the extreme site fidelity of adults (see above), this automatically excluded the possibility of incestuous mating between parents and their offspring (no such cases observed in BNP). The Marsh Tit results are thus consistent with data for other forest species (Greenwood et al. 1978; Schiegg et al. 2006; Szulkin and Sheldon 2008), which suggest that dispersal could serve as a primary mechanism of inbreeding avoidance. It remains to be seen, though, whether inbreeding avoidance has played a major role in shaping the evolution of dispersal in Marsh Tits, or whether it is simply an advantageous by-product of other selective pressures, such as avoidance of intra-specific competition between kin (Nilsson 1989). As the natal patch is already occupied (by parents and fledglings), the only way for a juvenile bird to find a vacant place to settle is to search elsewhere. Even in a homogenous, saturated habitat, such opportunities can always occur, due to the death of adults. In this case, a bird would have to compete for a free slot but it would be in competition with strangers and not outcompeting relatives. The alternative solution, of staying on the natal territory, would be far less beneficial as it would denote resignation from breeding and queuing for a breeding opportunity. This is known to occur in situations where dispersal is for some reasons restricted (e.g. by habitat availability, islands) and all suitable patches are permanently occupied. Such conditions frequently led to evolution of co-operative breeding systems (reviews in Brown 1987; Ligon 1999).

\section{Fragmentation}

Marsh Tits in BNP still live in extensive, relatively homogenous forest, where most birds can presumably spend their whole lives without ever leaving suitable habitat. These old growth deciduous stands also provide very stable conditions, which makes possible the extreme site tenacity of breeding adults. Birds adapted to such conditions have probably not evolved mechanisms for longdistance dispersal across inhospitable landscapes, so how might they respond to habitat fragmentation and the appearance of dispersal barriers? Other studies of Marsh Tit dispersal carried out in such fragmented forests (see above) allow for comparisons. These Marsh Tits have not changed their basic pattern of dispersal behaviour: all young leave their natal patch, natal dispersal is usually the greatest distance moved during a lifetime, there is extreme site tenacity from the first breeding onwards, and natal dispersal distances are broadly similar (Table 4). This is to be expected, as, depending on how recent and extensive was the habitat disruption, the reaction could differ. If fragmentation was a very recent phenomenon, then birds would probably just avoid venturing into open areas (Desrochers et al. 1999; Lens et al. 1999; reviews in Desrochers and Bélisle 2007; Moore et al. 2008) which would result in shorter dispersal distances. However, if habitat becomes extremely patchy, then birds have to increase dispersal distances to avoid extinction. Yet, as the dispersal distances can only be measured for successful individuals which managed to settle somewhere, the distribution of dispersal distances does not provide any information on dispersal failures, i.e. the proportion of 
young which fail to settle anywhere. This effect could be quite substantial, though. The review of Desrochers and Bélisle (2007) show that, of all parid species analysed, Marsh Tits are the most sensitive to fragmentation, being first to disappear from smaller, more isolated woodlots situated in more open landscapes. These findings are confirmed by intensive studies in a highly fragmented landscape in England (Alderman et al. 2011; Broughton 2012). Marsh Tits are reluctant to cross open areas, with gaps greater than around $100 \mathrm{~m}$ beginning to represent significant barriers to movement (Ludescher 1973; Broughton and Hinsley 2014). The presence of unoccupied patches and territories occupied by unpaired males observed in England (a phenomenon nonexistent in BNP; T. Wesołowski, unpublished) indicates that settlement failure of longer-dispersing females could be a problem for that Marsh Tit population (Dale 2001; Broughton 2012). Whereas birds in BNP can disperse in any direction while remaining in suitable habitat and being able to find conspecifics everywhere, the birds in the highly fragmented English woodlands have to move further between patches in order to encounter the same number of potential territories where they could settle, often crossing hostile landscapes, and may never find a suitable patch or a mate. Matthysen and Currie (1996) observed identical symptoms of reduced disperser success in another highly sedentary forest species, the Eurasian Nuthatch Sitta europaea. Such problems with natal dispersal seem to be a major factor in the widespread decline of Marsh Tits in Britain (Broughton and Hinsley 2014).

\section{Concluding remarks}

Studies of dispersal continue to be a hot topic, and the phenomenon continues to demand theoretical interest and generates much empirical work. However, these efforts concentrate largely on organisms living in fragmented, transient habitats (see "Introduction"). The dispersal of organisms living in spatially extensive, homogenous, longlasting environments remains largely unstudied. This is very unfortunate, as this very group of organisms tends to be the one that is most detrimentally affected by fragmentation and the appearance of dispersal barriers, so is of greatest conservation concern (Hunter 1996; Macdonald and Johnson 2001; Baguette et al. 2012). Studying the dispersal behaviour of this group of organisms is also of enormous value for basic science, as it is necessary for understanding the evolution of life histories, social behaviour, population genetics or even large-scale biogeographic patterns. Whereas birds in the temperate zone are rarely as sedentary as Marsh Tits (e.g. Eurasian Nuthatch, Matthysen and Currie 1996 or Crested Tit Lophophanes cristatus, Lens and Dhondt 1994; Bardin 2011), this habit is much more widespread in the tropics (review in Stutchbury and Morton 2001). An additional feature of such tropical habitats, apart from their temporal persistence and spatial homogeneity, is that they tend to be permanently saturated with territories which leads to scarcity of vacant, unoccupied patches in which dispersing juveniles could settle. In such conditions, dispersal becomes even more restricted, and young birds tend to stay on the natal territories and co-operative breeding often evolves (review in Brown 1987; Stutchbury and Morton 2001). Dispersal constraints could even be a significant contributor to the origin of the enormous diversification of tropical forest avifaunas (Salisbury et al. 2012). The problems of limited dispersal and the inability to cross barriers are not restricted to birds, as they are faced by numerous other organisms living in extensive, persistent environments (e.g. insects; van Dongen et al. 1994; Wesołowski and Rowiński 2006). A greater effort invested in studying such organisms in these environments would be productive.

Acknowledgments I heartily thank M. Cholewa, M. Czuchra, T. Kliś, G. Hebda, M. Maziarz, C. Mitrus, B. Orłowska, P. Rowiński and L. Tomiałojć for their participation in the field work in different periods. Linguistic help and comments of R.K. Broughton are also appreciated. The financial aid of the ALA, Schweizerische Vogelwarte, the Ministry of Environmental Protection \& Natural Resources, and the National Fund For Environmental Protection and Water Management helped to partially cover the costs of fieldwork in various periods. The final analysis was supported by an internal grant from the Faculty of Biological Science of Wrocław University.

Open Access This article is distributed under the terms of the Creative Commons Attribution License which permits any use, distribution, and reproduction in any medium, provided the original author(s) and the source are credited.

\section{References}

Alderman J, Hinsley SA, Broughton RK, Bellamy PE (2011) Local settlement in woodland birds in fragmented habitat: effects of natal territory location and timing of fledging. Landsc Res 36:553-571

Amann F (1997) Dispersal, territory establishment and behaviour of juvenile Marsh Tits Parus palustris. Ornithol Beob 94:5-18

Amann F (2003) Territory occupation and pair bond of Marsh Tits Parus palustris. Ornithol Beob 100:193-210

Bächler E, Hahn S, Schaub M, Arlettaz R, Jenni L, Fox JW, Afansyev V, Liechti F (2010) Year-round tracking of small trans-Saharan migrants using light-level geolocators. PLoS ONE 5:e9566

Baguette M, Legrand D, Fréville H, van Dyck H, Ducatez S (2012) Evolutionary ecology of dispersal in fragmented landscape. In: Clobert J, Baguette M, Benton TG, Bullock JM (eds) Dispersal ecology and evolution. Oxford University Press, Oxford, pp 381-391

Baker M, Nur N, Geupel GR (1995) Correcting biased estimates of dispersal and survival due to limited study area: theory and an application using wrentits. Condor 97:663-674

Bardin AV (2011) Territorialnoje povedenije i migracii hohlatoj sinicy. Rus Ornitol Žurn. 20:675-697 
Bardin AV, Markovets MY, Mikhaylov DV (1992) Movements of Marsh Tits (Parus palustris) along the Courish Spit according to the records of permanent trapping. In: Proceedings of Zoological Institute, St. Petersburg 247:7-17

Barrowclough GF (1978) Sampling bias in dispersal studies based on finite area. Bird Band 49:333-341

Berndt R, Winkel W (1987) Abundance dynamic and breeding data of Marsh Tits (Parus palustris). Results collected in south-east Lower Saxony. Vogelwelt 108:121-131

Bobiec A (2002) Living stands and dead wood in the Białowieża forest: suggestions for restoration management. For Ecol Manag 165:125-140

Bonte D, Van Dyck H, Bullock JM, Coulon A, Delgado M, Gibbs M, Lehouck V, Matthysen E, Mustin K, Saastamoinen M, Schtickzelle N, Stevens VM, Vandewoestijne S, Baguette M, Barton K, Benton TG, Chaput-Bardy A, Clobert J, Dytham C, Hovestadt T, Meier CM, Palmer SCF, Turlure C, Travis JMJ (2012) Costs of dispersal. Biol Rev 87:290-312

Broughton RK (2012) Habitat modelling and the ecology of the Marsh Tit (Poecile palustris). PhD thesis, Bournemouth University. http://nora.nerc.ac.uk/201719/

Broughton RK, Hinsley SA (2014) The ecology and conservation of the Marsh Tit Poecile palustris in Britain. Br Birds (in press)

Broughton RK, Hinsley SA, Bellamy PE, Hill RA, Rothery P (2006) Marsh Tit Poecile palustris territories in a British broad-leaved wood. Ibis 148:744-752

Broughton RK, Hill RA, Bellamy PE, Hinsley SA (2010) Dispersal, ranging and settling behaviour of Marsh Tits Poecile palustris in a fragmented landscape in lowland England. Bird Study $57: 458-472$

Brown JL (1987) Helping and communal breeding in birds. Princeton University Press, New Jersey

Bullock JM, Kenward RE, Hails RS (eds) (2002) Dispersal ecology. British Ecological Society, Oxford

Clarke AL, Saether B-E, Roskaft E (1997) Sex biases in avian dispersal: a reappraisal. Oikos 79:429-438

Clobert J, Danchin E, Dhondt AA, Nichols JD (eds) (2001) Dispersal. Oxford University Press, Oxford

Clobert J, Baguette M, Benton TG, Bullock JM (eds) (2012) Dispersal ecology and evolution. Oxford University Press, Oxford

Cramp S, Perrins CM (1993) The birds of the Western Palearctic, vol 7. Oxford Univeristy Press, Oxford

Czyż B, Rowiński P, Wesołowski T (2012) No evidence for offspring sex ratio adjustment in Marsh Tits breeding in a primeval forest. Acta Ornithol 47:111-118

Dale S (2001) Female-biased dispersal, low female recruitment, unpaired males, and the extinction of small and isolated bird populations. Oikos 92:344-356

Desrochers A, Bélisle M (2007) Edge, patch and landscape effects on Parid distribution and movements. In: Otter K (ed) The ecology and behavior of chickadees and titmice. Oxford University Press, Oxford, pp 243-261

Desrochers A, Hannon SJ, Bélisle M, Clair CCSt (1999) Movement of songbirds in fragmented forests: can we 'scale up' from behaviour to explain occupancy patterns in the landscape? In: Adams NJ, Slotow RH (eds). In: Proceedings 22 Int Ornithol Congr, Durban. BirdLife South Africa, Johannesburg, pp 2447-2464

Diamond JM (1981) Flightlessness and fear of flying in island species. Nature 293:507-508

Faliński JB (1986) Vegetation dynamics in temperate lowland primeval forest. Junk, Dordrecht

Greenwood PJ (1980) Mating systems, philopatry and dispersal in birds and mammals. Anim Behav 28:1140-1162

Greenwood PJ, Harvey PH (1982) The natal and breeding dispersal of birds. Ann uRev Ecol Syst 13:1-21
Greenwood PJ, Harvey PH, Perrins CM (1978) Inbreeding and dispersal in the great tit. Nature 271:52-54

Hamilton WD, May RM (1977) Dispersal in stable habitats. Nature 269:578-581

Hamlin I (2008). Recent rarities in Ayrshire (Marsh Tit). In: Simpson F (ed) Ayrshire bird report 2008, Scottish Ornithologists' Club (Ayrshire Branch), Ayr

Hunter AF (1995) The ecology and evolution of reduced wings in forest macrolepidoptera. Evol Ecol 9:275-287

Hunter ML Jr (1996) Fundamentals of conservation biology. Blackwell , Cambridge

Koenig WD, van Vuren D, Hooge PN (1996) Detectability, philopatry, and the distribution of dispersal distances in vertebrates. Trends Ecol Evol 11:514-517

Lens L, Dhondt AA (1994) Effects of habitat fragmentation on the timing of Crested Tit Parus cristatus natal dispersal. Ibis 136:147-152

Lens L, Adriaensen F, Matthysen E (1999) Dispersal studies in recently and historically fragmented forests: a comparison between Kenya and Belgium. In: Adams NJ, Slotow RH (eds). In: Proceedings 22 Int Ornithol Congr, Durban. BirdLife South Africa, Johannesburg, pp 2480-2491

Ligon JD (1999) The evolution of avian breeding systems. Oxford University Press, Oxford

Ludescher FB (1973) The Marsh Tit (Parus palustris) and the Willow Tit (Parus montanus) as sympatric sibling-species. J Ornithol 114:3-56

Macdonald DW, Johnson DDP (2001) Dispersal in theory and practice: consequences for conservation biology. In: Clobert J, Danchin E, Dhondt AA, Nichols JD (eds) Dispersal. Oxford University Press, Oxford, pp 358-372

Markovets MJ (2001a) Populjacionnaja ekologija gaički (Parus palustris). Avtoreferat dissertacii na soiskanie učenoj stepeni kandidata biologičeskih nauk. Rossijskaja Akademija Nauk, Zoologičeskij Institut, St. Peterburg

Markovets MJ (2001b) Demografija gaički na Kuršskoj Kose. In: Kuročkin EN, Rahimov II Aktualnyje problemy izučenija ohrany ptic Vostočnoj Evropy i Severnoj Azii. Ministerstvo Ohrany Okryžajuščej Sredy i Prirodnyh Resursov Respubliki Tatarstan, Kazaň, pp. 401-402

Matthysen E (2005) Density-dependent dispersal in birds and mammals. Ecography 28:403-416

Matthysen E (2012) Mulitcausality of dispersal: a review. In: Clobert J, Baguette M, Benton TG, Bullock JM (eds) Dispersal ecology and evolution. Oxford University Press, Oxford, pp 3-18

Matthysen E, Currie D (1996) Habitat fragmentation reduces disperser success in juvenile nuthatches Sitta europaea: evidence from patterns of territory establishment. Ecography 19:67-72

Meyburg B-U, Meyburg C (2009) Wanderung mit Rucksack: satellitentelemetrie bei Vögeln. Der Falke 56:256-263

Moore RP, Robinson WD, Lovette IJ, Robinson TR (2008) Experimental evidence for extreme dispersal limitation in tropical forest birds. Ecol Lett 11:960-968

Newton I (1979) Population ecology of raptors. Poyser, Berkhamsted

Niechoda T, Korbel J (2011) Puszczańskie olbrzymy. Towarzystwo Ochrony Krajobrazu, Białowieża

Nilsson JÅ (1989) Causes and consequences of dispersal in Marsh Tits: time as a fitness factor in establishment. Lund University, Lund

Nilsson JÅ, Smith HG (1985) Early fledgling mortality and the timing of juvenile dispersal in the Marsh Tit Parus palustris. Orn Scand 16:293-298

Paradis E, Baillie SR, Sutherland WJ, Gregory RD (1998) Patterns of natal and breeding dispersal in birds. J Anim Ecol 67:518-536

Pärt T (1991) Philopatry and age as factors influencing reproductive success in the collared flycatcher (Ficedula albicollis). Acta Univ Upsalensis 310:5-35 
Pasinelli G, Schiegg K, Walters JR (2004) Genetic and environmental influences on natal dispersal distance in a resident bird species. Am Nat 164:660-669

Roff DA (1994) The evolution of flightlessness: is history important? Evol Ecol 8:639-657

Rost R (1988) Entstehung, Fortbestand und Funktionelle Bedeutung von Gesangsdialekten bei der Sumpfmeise Parus palustris-ein Test von Modellen. Hartung-Gorre, Konstanz

Salisbury CL, Seddon N, Cooney RCh, Tobias JA (2012) The latitudinal gradient in dispersal constraints: ecological specialisation drives diversification in tropical birds. Ecol Lett $15: 847-855$

Schiegg K, Daniels SJ, Walters JR, Priddy JA, Pasinelli G (2006) Inbreeding in red-cockaded woodpeckers: effects of natal dispersal distance and territory location. Conserv Biol 131:544-552

Sellers RM (1984) Movements of coal, Marsh and Willow Tits in Britain. Ringing Migr 5:79-89

Southwood TRE (1962) Migration of terrestrial arthropods in relation to habitat. Biol Rev 37:171-214

StatSoft, Inc. (2011) STATISTICA (data analysis software system), version 10. www.statsoft.com. Accessed 27 May 2014

Stutchbury BJM, Morton ES (2001) Behavioral ecology of tropical birds. Academic, New York

Stutchbury BJ, Tarof SA, Done T, Gow E, Kramer PM, Tautin J, Fox JW, Afansyev V (2009) Tracking long-distance songbird migration by using geolocators. Science 323:896

Szulkin M, Sheldon BC (2008) Dispersal as a means of inbreeding avoidance in a wild bird population. Proc R Soc Lond B 275:703-711

Tomiałojć L, Wesołowski T (1990) Bird communities of the primaeval temperate forest of Białowieża, Poland. In: Keast A (ed) Biogeography and ecology of forest bird communities. SPB, The Hague, pp 141-165

Tomiałojć L, Wesołowski T (2004) Diversity of the Białowieża forest avifauna in space and time. J Ornithol 145:81-92

Tomiałojć L, Wesołowski T (2005) The avifauna of Białowieża Forest: a window into the past. Br Birds 98:174-193

Tomiałojć L, Wesołowski T, Walankiewicz W (1984) Breeding bird community of a primaeval temperate forest (Białowieża National Park, Poland). Acta Ornithol 20:241-310

van Dongen S, Backeljau T, Matthysen E, Dhondt AA (1994) Effects of forest fragmentation on the population structure of the winter moth Operophtera brumata L. (Lepidoptera, Geometridae). Acta Ecol 15:193-206

Wesołowski T (1989) Nest-sites of hole-nesters in a primaeval temperate forest (Białowieża National Park, Poland). Acta Ornithol 25:321-351
Wesołowski T (1995) The loss of avian cavities by injury compartmentalization in a primaeval European forest. Condor 97:256-257

Wesołowski T (1996) Natural nest sites of Marsh Tit (Parus palustris) in a primaeval forest (Białowieża National Park, Poland). Vogelwarte 38:235-249

Wesołowski T (1998) Timing and synchronisation of breeding in a Marsh Tit Parus palustris population from a primaeval forest. Ardea 86:89-100

Wesołowski T (1999) Marsh Tits (Parus palustris) are not excavators. Ibis 141:149

Wesołowski T (2000) Time saving mechanisms in the reproduction of Marsh Tits Parus palustris. J Ornithol 141:309-318

Wesołowski T (2001) Ground checks-an efficient and reliable method to monitor holes' fate. Ornis Fenn 78:193-197

Wesołowski T (2002) Antipredator adaptations in nesting Marsh Tits Parus palustris: the role of nest site security. Ibis 144:593-601

Wesołowski T (2005) Virtual conservation: how the European Union is turning a blind eye on its vanishing primeval forests. Conserv Biol 19:1349-1358

Wesołowski T (2006) Nest-site re-use: Marsh Tit Poecile palustris decisions in a primeval forest. Bird Study 53:199-204

Wesołowski T (2007) Primeval conditions-what can we learn from them? Ibis 149(suppl. 2):s64-s77. doi:10.1111/j.1474-919x. 2007.00721.x

Wesołowski T, Rowiński P (2006) Is there a cost of reproduction for Marsh Tit Parus palustris in a primeval forest? Ibis 148:126-132

Wesołowski T, Tomiałojć L, Mitrus C, Rowiński P, Czeszczewik D (2002) The breeding bird community of a primaeval temperate forest (Białowieża National Park, Poland) at the end of the 20th century. Acta Ornithol 37:27-45

Wesołowski T, Rowiński P, Mitrus C, Czeszczewik D (2006) Breeding bird community of a primeval temperate forest (Białowieża National Park, Poland) at the beginning of the 21th century. Acta Ornithol 41:55-70

Wesołowski T, Mitrus C, Czeszczewik D, Rowiński P (2010) Breeding bird dynamics in a primeval temperate forest over 35 years: variation and stability in a changing world. Acta Ornithol 45:209-232

Wiens JA (2001) The landscape context of dispersal. In: Clobert J, Danchin E, Dhondt AA, Nichols JD (eds) Dispersal. Oxford University Press, Oxford, pp 96-109

Williamson M (2002) Overwiew and suynthesis: the tale of the tail. In: Bullock JM, Kenward RE, Hails RS (eds) Dispersal ecology. British Ecological Society, Oxford, pp 431-443

Winkel W (1970) Hinweise zur Art- und Altersbestimmung von Nestlingen höhlenbrütender Vogelarten anhand ihrer Körperentwicklung. Vogelwelt 91:52-59 